\title{
RELATIONSHIP BETWEEN TOTAL IMUNOGLOBULIN E LEVEL AND INTENSITY OF WHIPWORM INFECTIONIN PRIMARY SCHOOL CHILDREN, MEDAN, NORTH SUMATERA
}

\author{
Endy Juli Anto, Leonard Kristian Sinaga, Jekson Martiar Siahaan
}

Faculty of Medicine, Universitas Methodist Indonesia, Medan

\begin{abstract}
Background: Helminth infections remain endemic disease, mainly in tropical developing countries. Immunity against a number of helminth infections has been associated with antiparasitic immunoglobulin-E (IgE). This study aimed to determine the correlation between total IgE level and intensity of whipworm infection in primary school children, Medan, North Sumatera.

Subjects and Method: This was a cross-sectional study conducted at primary school, Tanjung Pura, Langkat, Medan, North Sumatera in Augustus 2019. A total of 19 students was selected for this study. The dependent variable was intensity of whipworm egg. The study subjects were selected by purposive sampling method. The independent variable was total IgE level. The data for dependent variable was measured by Kato-Katz technique. The total IgE serum concentration was measured by ELISA. Data were analyzed by Spearman correlation test.

Results: There was a negative correlation between total IgE level and intensity of whipworm infection among primary school children in Medan $(r=-0.64 ; p=0.003)$.

Conclusion: There is a negative correlation between total IgE level and intensity of whipworm infection among primary school children in Medan.

Keywords: whipworm infection, IgE, children

Correspondence:

Leonard Kristian Sinaga. Faculty of Medicine, Universitas Methodist Indonesia, Medan, Indonesia. Email: Leonardsinagao8051970@gmail.com. Mobile: +6282361343969.
\end{abstract}

The $7^{\text {th }}$ International Conference on Public Health

Solo, Indonesia, November 18-19, 2020 | 256 https://doi.org/10.26911/the7thicph.03.76 